\title{
Membangun Kewirausahaan Seni Melalui Festival Dalam Bandung Isola Performing Arts Festival (BIPAF)
}

\author{
Neneng Yanti K. Lahpan', Bunga Dessri Nur Ghaliyah² \\ 'Prodi Antropologi Institut Seni Budaya Indonesia (ISBI) Bandung \\ Jalan Buahbatu 212 Bandung 40285 Indonesia \\ ${ }^{2}$ Praktisi Seni dan Pegiat Literasi Komunitas Serat Pena \\ Kinara Regency Blok E No 9 Bojongsoang Bandung \\ Ineneng.lahpan@gmail.com
}

\begin{abstract}
Wirausaha seni, khususnya di bidang seni pertunjukan, menjadi hal penting dalam kaitan dengan perkembangan ekonomi dan industri kreatif. Bidang ini mendapat perhatian khusus dari pemerintan dalam 4 tahun belakangan, dengan dibentuknya sebuah badan khusus, BEKRAF. Mengembangkan wirausaha seni di antaranya dapat dilakukan melalui festival. Tulisan ini mengambil studi kasus Bandung Isola Performing Arts Festival (BIPAF) yang telah meletakkan dasar wirausaha seni sejak tahun 2016. Dengan menggunakan metode kualitatif melalui pendekatan teori social enterpreneurship, penelitian ini menghasilkan sejumlah rumusan bahwa (1) BIPAF telah menawarkan sebuah model pengembangan wirausaha seni dengan model pasar seni pertunjukan (performing arts market) yang menggunakan site specific stage, yakni Villa Isola UPI Bandung, untuk mempromosikan bentuk karya tari dan atau teater tari inovatif berbasis tradisi dan kolaborasi, serta mempertemukan para kreator dengan stakeholdernya, sekaligus berperan dalam pelestarian seni budaya; (2) untuk menjaga kualitas karya yang dihasilkan, karya-karya yang ditampilkan di BIPAF melalui sejumlah tahapan seleksi dan kurasi, inkubasi, pertunjukan hingga evaluasi. Indikator keberhasilan program ini di antaranya terlihat pada meningkatkan kuantitas pementasan para pentolan BIPAF yang dikelola secara profesional oleh para pengelola event, baik di dalam maupun di luar negeri.
\end{abstract}

Kata kunci: wirausaha seni; festival seni; BIPAF; industri kreatif; ekonomi kreatif

\section{Building Artistic Entrepreneurship Through festival in Bandung Isola Performing Arts Festival (BIPAF)}

Art entrepreneurs, especially in the area of performing arts, have become important in terms of economic development and creative industries. The areas have received special attention from the government in the past 4 years, by forming a special body, BEKRAF. Developing arts entrepreneurs can be depeloved through festivals. This paper takes a case study of the Bandung Isola Performing Arts Festival (BIPAF) which has laid the foundations of art entrepreneurship since 2016. Using qualitative methods through a social entrepreneurship theory approach, this research found several aspects that are important to be noticed: (1) BIPAF has offered a model in developing artistic entrepreneurship that is a performing arts market model that uses a specific stage site, namely Villa Isola UPI Bandung, to promote innovative forms of dance/theater based on collaboration, and bring together creators with their stakeholders, as well as playing a role in the preservation of cultural arts; (2) to maintain the quality of the work produced, the works displayed at BIPAF go through several stages of selection and curation, incubation, performance and evaluation. Indicators used to measure the success of this program can be seen in increasing the number of performances of BIPAF performers who are managed professionally by event organisers, both at inside and outside the country.

Keywords: art entrepreneurship; art festival; BIPAF; creative industry; creative economy

Proses Review : 18 - 31 Agustus 2020, Dinyatakan Lolos: 7 September 2020 


\section{PENDAHULUAN}

Kewirausahaan seni tidak bisa dilepaskan dari bidang ekonomi kreatif sebagai sektor yang menaungi aktivitas wirausaha seni. Dalam hal ini, pemerintah memberikan perhatian serius bagi peningkatan dan pengembangan ekonomi kreatif tersebut. Hal itu di antaranya terlihat pada keputusan penting pemerintah dengan membentuk Badan Ekonomi Kreatif Indonesia (BEKRAF) pada tahun 2015 sebagai lembaga pemerintah nonkementerian yang bertanggungjawab langsung kepada presiden melalui Menteri Pariwisata. Hal itu disertai dengan diterbitkannya berbagai instruksi Presiden tentang Pengembangan Ekonomi Kreatif sebagai pengerak roda perekonomian nasional.

Istilah Ekonomi Kreatif sudah mulai dikenal sejak digelarnya Pekan Produk Budaya Indonesia yang pertama kali diselenggarakan pada tahun 2007. Dalam OPUS-BEKONOMI KREATIF Outlook (2017: 17), BEKRAF mendefinisikan Ekonomi Kreatif sebagai "penciptaan nilai tambah berbasis ide yang lahir dari kreativitas sumber daya manusia (orang kreatif) dan berbasis pemanfaatan ilmu pengetahuan, termasuk warisan budaya dan teknologi." Sebagai sebuah konsep ekonomi yang terbilang baru, Ekonomi Kreatif mengandalkan gagasan, ide, atau kreativititas dari Sumber Daya Manusia (SDM) sebagai faktor produksi utama dalam kegiatan ekonominya. Dalam hal ini, Ekonomi Kreatif diyakini mampu menjadi poros ekonomi terbaru Indonesia di masa mendatang yang diprediksi dapat memberi dampak besar bagi perekonomian. Ekonomi kreatif juga dianggap bisa menjadi motor penggerak perekonomian baru yang membawa perubahan secara masif dan sistematis (2017: 20).

Dalam kaitan dengan itu, pengembangan potensi industri kreatif, sebagaimana dikemukakan Nurchayati dan Ratnawati (2016: 811), dapat memberi dampak positif pada kehidupan sosial, iklim bisnis, peningkatan ekonomi, dan juga citra suatu kawasan. Hal ini disebabkan industri kreatif yang mengedepankan inovasi dan kreativitas dapat melahirkan inovasi-inovasi yang akan mendorong rasa ingin tahu orang untuk mendatangi tempat-tempat baru tersebut.

Atas dasar berbagai dampak positif yang dihasilkannya, ekonomi kreatif pun dikembangkan dalam berbagai bidang di dalam masyarakat, termasuk bidang seni.

Koentjaraningrat (2002: 1) mengungkapkan bahwa kesenian adalah ciptaan dari segala pikiran dan perilaku manusia yang fungsional, estetis dan indah, sehingga dapat dinikmati dengan panca indera, yaitu pengelihatan, penciuman, pengecapan, pendengaran, dan perasaan. Dalam hal ini, seni tak bisa dilepaskan dari budaya lokal, termasuk di dalamnya seni tradisi. Oleh karena itu, kewirausahaan dalam dunia seni, yang mengangkat, melakukan pengembangan dan inovasi terhadap seni tradisi yang merupakan kekayaan budaya di Indonesia, perlu untuk terus dikembangkan. Hal tersebut sebagaimana diungkapkan oleh Bahren dkk (2014: 134), bahwa kekayaan budaya lokal menjadi bagian identitas penting dalam industri kreatif, karena dapat menjadi ikon yang melibatkan masyarakat sehingga perkembangan industri dapat dinikmati secara bersama. Selain itu, industri kreatif yang berbasis budaya lokal juga dapat membantu keberlangsungan budaya tersebut, tanpa merusak, tetapi sebaliknya akan mendukung kebudayaan itu sendiri untuk terus hidup dan berkembang. Dengan demikian, dapat dikatakan bahwa seni merupakan wilayah strategis untuk menjalankan ekonomi kreatif melalui wirausaha seni. Dalam hal ini, para seniman pun dituntut untuk memiliki jiwa kewirausahaan.

Enterpreneurship atau kewirausahaan dalam dunia seni dapat dilakukan melalui berbagai cara dan strategi, salah satunya yakni melalui festival atau event. Any dalam Khairil dan Ranti (2018: 79) mengemukakan definisi event sebagai berikut:

Event adalah suatu kegiatan yang diselenggarakan untuk memperingati hal-hal penting sepanjang hidup manusia; baik secara individu maupun kelompok yang terikat secara adat, budaya, tradisi dan agama. Event diselenggarakan untuk tujuan dan waktu tertentu serta melibatkan kelompok masyarakat.

Khairil dan Ranti (2018: 79) mengemukakan bahwa festival atau event merupakan salah satu strategi dalam upaya pengembangan nilai budaya yang dapat menarik perhatian dan minat masyarakat. Pengembangan nilai budaya melalui instrumen kegiatan demikian, banyak dimanfaatkan oleh berbagai kalangan untuk memperkenalkan diri atau komunitasnya kepada khalayak dalam berbagai bentuk karya. Zulfajri (2019: 3) mengemukakan bahwa kegiatan yang mempertunjukkan produk budaya dalam bentuk festival menjadi salah satu produk wisata yang tidak kalah menarik dibandingkan dengan destinasi wisata lainnya, seperti wisata alam, wisata religi, dan sebagainya.

Salah satu festival yang dilakukan secara berkala dan mengandung unsur pengembangan enterpreneurship adalah Bandung Isola Performing Arts Festival (BIPAF). BIPAF digelar setiap tahun oleh Universitas Pendidikan Indonesia (UPI) Bandung sejak tahun 2016, untuk menyajikan dan mempromosikan produk kreatif dan inovatif para seniman, khususnya di Bandung dan sekitarnya, agar dapat mendapat keuntungan secara sosial, ekonomi, dan budaya. BIPAF diselenggarakan untuk membangun ekosistem seni, antara seniman dengan pelaku industri, agar terjadi sinkroninasi antara seni dan kebutuhan industri. Di sini, BIPAF berperan penting dalam meningkatkan kualitas dan 'daya jual' seni yang ditampilkannya agar semakin diminati oleh user, dalam hal ini buyer atau para stakeholder yang berkepentingan terhadap penyajian seni yang berbasis tradisi tersebut. Dampak positif BIPAF telah dirasakan oleh para peserta, di antaranya dengan meningkatnya 
kualitas dan kuantitas produksi para seniman yang terlibat dalam kegiatan tersebut di ruang lingkup yang lebih besar, baik itu di kalangan seniman di Indonesia maupun di mancanegara. Atas dasar sistem entrepreneurship yang dibangun melalui festival ini serta dampak positifnya, BIPAF menjadi objek yang menarik untuk dikaji.

\section{METODE}

\section{Jenis Penelitian dan Metode Pengumpulan Data}

Penelitian ini bersifat kualitatif. Dalam mengumpulkan data, penulis melakukan berbagai metode, yakni (1) studi pustaka. Sumber pustaka dalam tulisan ini adalah berbagai referensi yang terkait dengan festival, khususnya BIPAF, kewirausahaan, ekonomi kreatif, dan teori social entrepreneurship; (2) Wawancara terhadap sejumlah narasumber, di antaranya Juju Masunah selaku salah satu penggagas BIPAF, panitia BIPAF, pengisi acara BIPAF, para apresiator BIPAF, dan sebagainya; (3) Observasi. Penulis melakukan dua jenis observasi, yang pertama observasi partisipan yakni ketika salah seorang penulis (Bunga Dessri) menjadi salah satu penata musik dalam BIPAF tahun 2016; dan observasi nonpartisipan, yakni melakukan pengamatan terhadap BIPAF dengan tidak terlibat langsung, atau hanya mengamati sebagai orang luar.

\section{Teori Social Enterpreneurship}

Saat ini adalah era industri kreatif. Menurut DCMS (Creative Digital Industries National Mapping Project ARC Centre of Excellent for Creative Industries and Innovation, 2007) dalam Nurchayati dan Ratnawati (2016: 811), industri kreatif adalah industri yang berasal dari pemanfaatan kreativitas, keterampilan serta bakat individu untuk menciptakan kesejahteraan serta lapangan pekerjaan melalui penciptaan dan pemanfaatan daya kreasi dan daya cipta individu tersebut. Sementara itu, Departemen Perdagangan Republik Industri dalam buku Pengembangan Industri Kreatif Menuju Visi Ekonomi Kreatif 2025, mengelompokkan industri kreatif menjadi 14 subsektor, dan dalam perkembangannya ditambah satu subsektor. Kelimabelas subsektor itu adalah periklanan (advertising), arsitektur, pasar barang seni, kerajinan (craft), desain, fashion, video/ film/fotografi, permainan interaktif (interactive games), musik, seni pertunjukan (showbiz), penerbitan/percetakan, layanan komputer/piranti lunak (software), televisi/radio (broadcasting), riset/pengembangan (riset and developement), dan kuliner.

Dalam era industri kreatif ini, dikenal sebuah istilah bernama social entrepreneurship, yakni sebuah istilah yang menggabungkan pemberdayaan sosial dan ilmu kewirausahaan untuk menjadi salah satu alternatif untuk mengurangi permasalahan sosial dan ekonomi di masyarakat. Light dalam Ridwan (2015: 48) mengungkapkan bahwa kewirausahaan sosial adalah sebuah usaha untuk memecahkan masalah sosial yang saling berkaitan dan saling bergantung melalui perubahan-perubahan dan mendobrak pola-pola yang sudah ada. Selanjutnya, Juwaini dalam Fittria (2016:2) menjelaskan bahwa social enterpreneurship berbeda dengan business enterpreneurship, karena social enterpreneurship apabila memiliki keuntungan dari aktivitas ekonomi, maka kekayaan tersebut bukan untuk memperkaya diri sendiri, melainkan untuk menolong masyarakat maupun komunitas yang diberdayakan. Smallbone et al dalam Fittria (2017: 12) memberikan beberapa contoh misi sosial usaha social entrepreneurship, sebagai berikut: 1. To provide goods and services which the market or public sector is either unwilling or unable to provide (untuk menyediakan barang dan jasa yang ada di pasaran atau di sektor publik yang ketersediaannya terbatas atau tidak tersedia);

2. To develop skills (untuk mengembangkan kemampuan);

3. To create employment (untuk menciptakan lapangan pekerjaan); dan

4. To foster pathways to intergrate socially excluded people (untuk membantu membukakan akses bagi orang-orang yang tereksklusi secara sosial).

Widiastuti dan Margaretha (2011: 1) mengemukakan bahwa kehadiran para Social Enterpreneur sangat dibutuhkan sebagai bagian dari solusi untuk menciptakan perubahan positif atas permasalahan sosial di masyarakat, seperti pengangguran, ekonomi, pendidikan, dan sebagainya. Des dalam Widiastuti dan Margaretha (2011:2) menambahkan bahwa social enterpreneur dapat bertindak sebagai agen perubahan bagi lingkungan, mencari kesempatan/peluang, memperbaiki sistem, menemukan pendekatan yang baru, serta mencari solusi terhadap perubahan lingkungan yang lebih baik. Sedangkan Bielefeld (2009: 72) mengemukakan bahwa social enterpreneurship mengukur keberhasilannya dari manfaat yang dirasakan masyarakat (nilai-nilai sosial), tidak seperti usaha biasa yang mengukur keberhasilan dari kinerja yang bersifat ekonomis (keuntungan/ pendapatan).

Berdasarkan penjelasan di atas, BIPAF dapat dianalisis dengan menggunakan teori social enterpreneurship. Sebagai salah satu subsektor dalam ekonomi kreatif, BIPAF menjadikan seni pertunjukan (showbiz) sebagai alat untuk memajukan para seniman dan keseniannya. Dalam aktivitas ini, terkandung pula misi terkait pelestarian kebudayaan yang melatarbelakanginya. Di dalam BIPAF, terdapat berbagai elemen kewirausahaan yang perlu untuk ditelaah sehingga dapat dijadikan contoh, referensi, bahkan motivasi, khususnya bagi para pelaku seni.

\section{HASIL DAN PEMBAHASAN}

\section{BIPAF dan Wirausaha Seni}

Di bawah pemerintahan Presiden Joko Widodo, pada tanggal 20 Januari 2015, dibentuk Badan Ekonomi Kreatif (BEKRAF) melalui Peraturan Presiden Republik Indonesia Nomor 6 Tahun 2015 tentang Badan Ekonomi Kreat- 
if. Dalam OPUS-BEKONOMI KREATIF Outlook (2017: 18) dikemukakan bahwa BEKRAF merupakan lembaga non-kementerian yang bertanggung jawab terhadap keseluruhan perkembangan ekonomi kreatif di Indonesia. BEKRAF mengemban mandat langsung dari Presiden untuk memajukan dan mengembangkan Ekonomi Kreatif di Indonesia, serta bertugas membantu Presiden dalam merumuskan, menetapkan, mengoordinasikan, dan melakukan sinkronisasi kebijakan di bidang Ekonomi Kreatif.

Hal itu sesuai dengan misi pemerintah, seperti disampaikan Presiden Joko Widodo dalam OPUS-BEKONOMI KREATIF Outlook (2017: 18) bahwa ekonomi kreatif harus mampu menjadi penggerak roda perekonomian nasional di masa mendatang. Presiden juga menyadari potensi Indonesia dalam bidang-bidang berbasis kreativitas dan juga pentingnya memberikan porsi khusus dalam merumuskan kebijakan-kebijakan yang memajukan sektor-sektor berbasis kreativitas tersebut, yang telah mulai dilakukan sejak tahun 2005 lalu.

Berangkat dari ekonomi kreatif yang berkembang di Indonesia serta berbagai pengalaman, hasil penelitian dan penciptaaan karya seni yang mencakup pertunjukan tari, teater tari, dan gending karesmen yang telah dilakukan, maka Juju Masunah dan dua orang dosen Fakultas Pendidikan Seni dan Desain (FPSD) lainnya, yakni Yudi Sukmayadi dan Trianti Nugraheni telah mendorong lahirnya BIPAF yang berbasis pada semangat wirausaha seni.

BIPAF lahir dengan proses yang terencana melalui riset yang mendalam. Dalam acara Worskshop Call For Tenants ISBI Bandung (29/10/2019), Masunah mengungkapkan bahwa BIPAF diciptakan tidak hanya untuk hiburan, melainkan untuk membangun suatu ekosistem seni, yakni kesinambungan antara apresiasi, pendidikan, kreasi, produksi, distribusi, presentasi, serta penonton. Selain itu, di dalam festival tersebut juga terdapat sinergitas antara seni dan kewirausahaan. Hal tersebut dijelaskan lebih terperinci dalam wawancara sebaga berikut.

Seni tradisi bisa mati. Cara untuk menanggulanginya adalah dengan membangun suatu tempat hidup untuk kesenian tersebut. Sekarang misalnya sudah ada lembaga pendidikan seni seperti UPI dan ISBI, yang di dalamnya ada mata kuliah misalnya tari tradisi dan kreasi (komposisi), tapi itu tidak cukup, karena nyatanya dalam perkuliahan, kreativitas menjadi terbatas. Terbatas misalnya setelah ujian dan mendapat nilai lalu karya yang telah diciptakan tidak dikembangkan atau ditampilkan lagi sehingga tidak mendatangkan manfaat yang lebih besar. Atas dasar hal itu, apalagi saat ini kan era ekonomi kreatif, maka diciptakanlah BIPAF, agar karya mahasiswa dan para seniman tidak hanya menjadi tontonan sesaat dan berhenti begitu saja, melainkan menjadi dikenal dalam cakupan yang lebih luas, dan mendatangkan manfaat-manfaat lainnya" (Wawancara, 29/102019).
Selain itu, gagasan diselenggarakan BIPAF pun didorong oleh pengalaman Masunah sebagai akademisi, serta pengalamannya yang pernah berkiprah dalam ruang lingkup Kementrian Pariwisata. Masunah menegaskan bahwa BIPAF merupakan wadah untuk memunculkan karya seni pertunjukan inovatif dari wilayah Bandung dan sekitarnya, karena pada saat terselenggaranya event pasar seni pertunjukan terbesar, yaitu Indonesia Performing Arts Market (IPAM) 2013 di Jakarta, tak satupun seniman Bandung dan sekitarnya ikut berpartisipasi. Sedangkan, para seniman lain dari Yogyakarta, Surakarta, Padang, bahkan NTT turut berpartisipasi. Hal itu merupakan penanda bahwa di Bandung, arts market atau kewirausahaan seni belum berkembang. Hal tersebut membuat Masunah semakin bertekad untuk menciptakan arts market seperti IPAM, PAMS, dan sebagainya di Bandung (Wawancara, 17 September 2019).

Dalam kaitan dengan itu, Rahayu (2016) mengungkapkan bahwa seni dan kewirausahaan atau enterpreneurship sejatinya seperti dua sisi mata uang yang tidak bisa dipisahkan. Di satu sisi, seorang enterpreneur dituntut untuk tetap memiliki jiwa seni agar manajemen perusahaan lebih fleksibel, kreatif, dan inovatif. Di sisi lain, seorang seniman juga harus mempunyai jiwa wirausaha agar hasil karya seninya bernilai ekonomis dan memiliki selling point tinggi di masyarakat.

Dalam hal ini, Masunah dalam Workshop Call For Tenants ISBI Bandung (29/10/2019) mengungkapkan pentingnya kesinambungan antara seni dan kewirausahaan, sebagai berikut:

Seni harus berubah. Kesenian itu multidisplin, fungsi ritual, sosial, culture dan education, juga ekonomi. Seni bukan hanya untuk seni, seni bisa menghasilkan ekonomi. Para seniman, terutama lulusan akademisi seni, seharusnya bukan menjadi job seeker, namun harus menjadi job provider. agar kesinambungan antara seni dan kewirausahaan dapat terwujud.

Pentingnya sentuhan bisnis bagi seniman juga diungkapkan oleh Presiden Direktur Ciputra Artpreneur, Rina Ciputra Sastrawinata dalam Rahayu (2016) yang mengatakan, "Pendidikan kewirausahaan bagi pelaku seni menjadi penting, mengingat banyak yang belum maksimal dalam menjual karya seninya karena kurang pengetahuan dalam pengembangan bisnis". Hal serupa disampaikan Kepala Badan Ekonomi Kreatif RI, Triawan Munaf, bahwa konsep ekonomi kreatif memberikan kesadaran bagi para pelaku seni bahwa penggabungan nilai seni dan bisnis merupakan alat utama untuk mencapai kemandirian ekonomi berbasis seni. Dalam hal ini, pelaku dan pekerja seni Indonesia perlu menyadari bahwa saat ini industri kreatif dapat menjadi sumber utama mata pencaharian, bukan sekedar hobi. Atas dasar hal tersebut, seni dan kewirausahaan dapat saling melengkapi, dan BIPAF merupakan salah satu contoh wadah untuk merealisasikan sinergitas tersebut. 


\section{BIPAF dan Manajemen Seni}

Untuk menciptakan ekosistem seni yang berkualitas, diperlukan manajemen dan Sumber Daya Manusia (SDM) yang baik. Dewiyanti, dkk (2017: 247) menyatakan bahwa strategi diperlukan untuk mengoptimalkan sumber daya unggulan dalam memaksimalkan pencapaian sasaran kinerja. Salah satu contoh strategi tersebut dibahas oleh Bahren, dkk (2014: 134), bahwa dalam industri kreatif harus ada kelompok kreatif yang mengembangkan ide-ide dan produk kreatif berdasarkan pada kekuatan intelektual, seni budaya, teknologi sesuai perkembangan zaman, yang muncul atas dasar kebutuhan masayarakat yang berubah. Berkaitan dengan BIPAF, Masunah dkk. (2018: 171) menegaskan hal serupa, yakni pentingnya manajemen mulai perencanaan hingga evaluasi, seperti dikemukakan sebagai berikut.

Dalam menerapkan sebuah festival, dibutuhkan konsep manajemen, mulai dari perencanaan, implementasi, pemantauan, hingga evaluasi. Perencanaan dilakukan pada tahap persiapan, terutama dalam merancang model festival dan memilih seni pertunjukan. Pemilihan karya didasarkan pada kesiapan koreografer untuk menjelajahi panggung yang beruada di luar ruangan. Aspek penting lainnya adalah pembentukan tim kreatif yang menangani panggung, bakat, dan penonton. Contohnya, yakni seorang manager dibutuhkan untuk mengelola panggung/pertunjukan; pengaturan keluar masuknya para penonton, pengaturan percahayaan, tata suara, dan sebagainya, yang seluruhnya terus saling terhubung dan terorganisir.

Apa yang dikemukakan oleh Masunah tersebut, dapat terlaksana dengan baik (potensial) bila didukung oleh tiga hal, sebagaimana diungkapkan oleh Ratnawati (2016:812), yaitu Knowledge Creative (pengetahuan yang kreatif), Skilled Worker (pekerja yang berkemampuan), dan Labor Intensive (kekuatan tenaga kerja). Dalam BIPAF, ketiga hal itu dapat diidentifikasi dari inisiatornya, yakni Juju Masunah, panitia (yang kini telah tergabung dalam sebuah wadah bernama BIPAF community), pendonor, para seniman, serta para apresiator (penonton, pemerhati, buyer, dan sebagainya).

\section{Inisiator}

BIPAF merupakan festival yang digagas berdasarkan penelitian tindakan berbasis projek (project based research) yang dilaksanakan oleh Prof. Juju Masunah, M.Hum., Ph.D, Dr. Phil. Yudi Sukmayadi, M.Pd, dan Dr. Trianti Nugraheni, M.Si. dari Fakultas Pendidikan Seni dan Desain UPI. Pada tahun 2018 tema yang diusung adalah "Bandung Isola Arts Festival (BIPAF) Sebagai Wadah Promosi Karya Seni Pertunjukan Innovatif di Kota Bandung”. Hal tersebut menunjukkan bahwa bahwa BIPAF digagas oleh SDM yang memiliki intelektualitas yang mumpuni serta kemampuan dan keterampilan yang tidak diragukan di bidang seni. Dengan kata lain, BIPAF adalah hasil karya intelektual bidang seni yang hendak berkontribusi pada hilirisasi penelitian berupa sebuah produk festival yang bermanfaat bagi masyarakat seni, khususnya di Kota Banudng.

Kasus BIPAF ini menunjukkan bahwa seorang akademisi di perguruan tinggi pun perlu memiliki social entrepreneur seperti ditunjukkan oleh Masunah dkk. Beberapa contoh karakteristik social enterpreneur dapat diidentifikasi dari Borstein dalam Widiastuti dan Margaretha (2011: 3) di antaranya, memiliki visi untuk memecahkan masalah kemasyarakatan sebagai pembaharu masyarakat dengan gagasan-gagasan yang sangat kuat untuk memperbaiki taraf hidup masyarakat; memiliki daya transformatif; mengubah daya kinerja masyarakat dengan cara memperbaiki, memperkuat, dan memperluas cita-cita; pemecah masalah paling kreatif; tidak bisa tinggal diam dan ingin memecahkan masalah yang gagal ditangani oleh pranata (negara dan mekanisme pasar); melampaui format-format lama dan terdorong untuk menemukan format bentuk-bentuk baru organisasi; lebih bebas, independen, dan memilih keterlibatan yang lebih produktif; dan sebagainya.

Social entrepreneur di dunia pendidikan menjadi salah satu kata kunci yang dapat mendorong untuk terwujudnya transformasi sosial, dengan mencari solusi bagi permasalahan yang dihadapi seniman. Hal inilah yang ditunjukkan Masunah dan timnya. Mereka secara transformatif dan kreatif menciptakan gagasan baru untuk memperbaiki keadaan dan taraf hidup para seniman. Hal itu diimplementasikan melalui kapasitasnya sebagai pendidik di dalam lingkup kampus UPI.

\section{Panitia dan Pendonor}

BIPAF dikelola oleh komunitas yang dibentuk secara khusus di UPI Bandung bernama BIPAF Community. Menurut Aidi Supri (wawancara, 20 Maret 2019), ketua panitia BIPAF 2018, unsur kepanitiaan merupakan salah satu kekurangan di dalam managemen BIPAF. Ia mengatakan, "BIPAF tidak memiliki kepanitiaan khusus, jadi manajeman dan produksi ditangani oleh Prof. Juju secara langsung dan dibantu oleh mahasiswa serta alumni yang saat itu sekaligus menjadi penari (pengisi acara) dalam event tersebut. Jadi, performer memiliki beban ganda, karena merangkap juga sebagai panitia". Walaupun demikian, kekurangan yang dikemukakan Supri pun sebetulnya dapat dilihat sebagai kelebihan, karena BIPAF Community terdiri atas para mahasiswa serta para alumni jurusan seni, maka hal itu dapat dilihat sebagai bentuk pemberdayaan SDM. Terlebih mereka umumnya sudah memahami pertunjukan, dan mudah diarahkan dalam hal manajemen produksi. Keterlibatan mahasiswa dan alumni menjadi nilai lebih dalam konteks pemberdayaan dan pengembangan SDM serta memberikan pengalaman bagi mereka dalam membuat sebuah festival.

Selain itu, BIPAF memiliki kelebihan dalam hal lokasi dan pendanaan. Dalam hal ini, Supri menjelaskan bahwa loka- 
si BIPAF menjadi kelebihan tersendiri karena merupakan festival UPI sehingga lokasi kegiatan pun berada di lingkup kampus tersebut. Kemudian. Dalam aspek pendanaan, BIPAF relative tidak memiliki kendala karena mendapat dukungan dana penelitian. Pendanaan tersebut didapatkan dari DIKTI, LPPM, dan berbagai sumber lain. Selain itu, BIPAF pun disinergikan menjadi bagian dari kegiatan Dies Natalies UPI sehingga universitas memberikan pos pendanaan khusus untuk terselenggaranya kegiatan ini (wawancara, 20 Maret 2019).

\section{Pelaku Seni dan Apresiator}

BIPAF memiliki sejumlah perbedaan dengan festival lainnya. Salah satunya yakni adanya proses panjang hingga suatu karya bisa ditampilkan dalam BIPAF. Masunah dkk (2018: 171) menyatakan bahwa BIPAF diproduksi melalui serangkaian kegiatan seleksi dan kurasi, lalu inkubasi, promosi, pertunjukan (showcasing), paparan (pitching), diskusi, kemudian evaluasi. Jadi, untuk menampilkan karyanya di BIPAF, para peserta mengikuti berbagai rangkaian kegiatan yang dipantau oleh para ahli yang telah ditunjuk oleh panitia BIPAF.

Para seniman yang ingin menjadi performer dalam BIPAF harus mengirimkan proposal, portofolio, serta persyaratan lainnya untuk proses seleksi dan kurasi. Setelah lolos seleksi, diadakan inkubasi untuk meningkatkan kualitas produk yang masih dalam tahap proses kreatif. Setelah itu, karya tersebut dipromosikan ke berbagai media untuk mendatangkan berbagai pihak terkait (seperti buyer dan stakeholder lainnya) pada tahapan acara berikutnya, yaitu showcase atau pertunjukan. Masunah dkk (2018: 172) mengungkapkan bahwa BIPAF dihadiri oleh berbagai macam latar belakang, dari mulai pencipta, praktisi, anggota komite, pekerja kreatif, pengamat, dan sebagainya.

Dalam pertunjukan, karya-karya yang ditampilkan pun diapresiasi oleh para buyer dari festival ataupun organisasi lain, baik dari dalam maupun luar negeri. Masunah (2018:171) pun menyatakan bahwa salah satu keunggulan BIPAF adalah mengundang pembeli, termasuk direktur festival dan promotor, serta memfasilitasi dialog atara performer dan buyer. Dengan demikian, para kreator yang terlibat dalam BIPAF akan memiliki kesempatan yang lebih besar untuk menampilkan karya-karyanya di panggung lain, baik di dalam maupun di luar negeri. Secara keseluruhan, target penonton berumlah 500 orang, namun pada praktiknya melebihi jumlah yang ditargetkan, yakni mencapai 1.000 orang. Masunah pun menambahkan bahwa kehadiran pengamat sangat penting, karena mereka diharapkan dapat menanggapi penampilan para performer untuk pengembangan kualitas artistik dan jaringan pasar.

\section{Kolaborasi dan Inovasi}

Kolaborasi dan inovasi merupakan sebuah komponen penting dalam membangun wirausaha seni. BIPAF, sebagai hasil karya akademik melakukan kolaborasi dengan pemer- intah kota Bandung dengan tujuan untuk mengembangkan nilai tambah produk seni pertunjukan dan kewirausahaan. Hal tersebut sebagaimana diungkapkan oleh Masunah dkk (2018: 170), bahwa BIPAF bertujuan untuk memfasilitasi seniman seni pertunjukan, pencipta, pemain, dan pekerja kreatif untuk melakukan pekerjaan mereka, menghasilkan kolaborasi dan koneksi dengan para pemangku kepentingan yang berkala nasional dan internasional.

Masunah dkk (2018: 171) mengungkapkan bahwa referensi konsep dasar BIPAF mengadopsi dari IPAM 2013 yang diselenggarakan oleh Kementerian Pariwisara dan Ekonomi Kreatif dan PAMS 2015. BIPAF merupakan acara yang menghadirkan dan mempromosikan produk kreatif dan inovatif yang dikurasi untuk didistribusikan dan memfasilitasi kolaborasi pertukaran ide di antara seniman. Hal tersebut sebagaimana yang dikemukakan oleh kepala Badan Ekonomi Kreatif RI, Triawan Munaf dalam Rahayu (2016) yang menyatakan bahwa pencapaian kesuksesan harus disertai dengan kejelian, keuletan, dan kemampuan para pelaku seni untuk selalu berusaha memberikan karya terbaik dan memberikan nilai ekonomis yang tinggi bagi karyanya melalui pengembangan bisnis, seperti kolaborasi dengan beragam industri yang dapat menggunakan karya seni secara kreatif, sehingga keberlangsungan hidup dan karya dapat terjamin masa depannya.

Festival pada umumnya hanya berorientasi pada penampilan para performer dan hiburan bagi para apresiator, namun BIPAF tidak terbatas pada hal tersebut. Di dalam rangkaian kegiatan BIPAF terdapat inovasi sebagaimana dikemukakan oleh Masunah (2018: 171) berikut ini:

Seni pertunjukan inovatif di BIPAF diproduksi melalui serangkaian kegiatan: seleksi dan kurasi, inkubasi, promosi, menampilkan dan melempar, diskusi, dan evaluasi. Langkah pertama dalam menentukan pekerjaan adalah pemilihan dan kurasi pekerjaan oleh para ahli ditunjuk oleh komite BIPAF. Setelah seleksi, menu Komite mengadakan kegiatan inkubasi untuk meningkatkan kualitas pekerjaan yang masih dalam proses kreatif atau penyesuaian ke tahap spesifik BIPAF. Dalam inkubasi seni ini proses, tim ahli menentukan bentuk presentasi, baik menampilkan atau pitching. Kemudian dipilih karya dipromosikan melalui berbagai media untuk juga mengundang pemangku kepentingan atau pembeli (Venue SIPA, Venue IMF, Venue IDF, Venue PAMS \& Andong Festival, Salihara, Festival Aroud the World).

BIPAF menggunakan model moving festival yang menggunakan landscape Villa Isola di kampus UPI Bandung yang menggabungkan pertunjukan seni tradisional, populer, dan kontemporer Indonesia. BIPAF menjadi ajang mempromosikan karya seni pertunjukan dari mahasiswa, dosen, dan komunitas, agar dapat diapresiasi oleh masyarakat dan berbagai pihak lainnya. BIPAF menampilkan seni pertunjukan di beberapa titik, baik indoor maupun outdoor, yang 
melibatkan berbagai aktivitas dalam rangkaian festival ini, seperti workshop, pameran seni rupa, dan sebagainya.

Dari paparan di atas dapat disimpulkan bahwa BIPAF dapat dijadikan sebagai model pasar seni pertunjukan (performing arts market) yang menggunakan site specific stage, yakni Villa Isola UPI Bandung, untuk mempromosikan bentuk karya tari dan atau teater tari inovatif berbasis tradisi dan kolaborasi, mempertemukan para kreator dengan stakeholdernya, sekaligus berperan dalam pelestarian seni budaya. Manfaat dari kegiatan ini telah dirasakan oleh sejumlah peserta yang pernah terlibat, yakni dengan meningkatnya undangan dari buyer serta kesempatan untuk pentas yang semakin tinggi melalui pengelolaan yang professional.

\section{PENUTUP}

BIPAF merupakan wadah publikasi karya cipta seni pertunjukan terkurasi, serta wadah bertemunya para pelaku seni, pencipta seni, koreografer, produser seni pertunjukan, yang kemudian berdiskusi dan berkolaborasi untuk membangun komunitas seni pertunjukan yang responsif terhadap industri kreatif. Hal tersebut sesuai dengan misi yang diemban oleh Masunah dkk, yakni menciptakan model festival sebagai wadah promosi karya seni pertunjukan inovatif; menganalisis bentuk-bentuk karya seni pertunjukan innovatif dalam BIPAF; dan menciptakan jejaring di antara seniman seni pertunjukan dan stakeholdernya.

Dalam hal ini, BIPAF dikategorikan sebagai social enterpreneurship, bukan kewirausahaan konvensional. Hal tersebut berdasarkan beberapa alasan, yakni:

1. BIPAF mengukur keberhasilannya dari manfaat yang dirasakan masyarakat (social value), tidak seperti kewirausahaan konvensional yang mengukur keberhasilannya melalui profit (keuntungan/pendapatan);

2. Misi BIPAF adalah untuk meningkatkan kesejahteraan bersama (khususnya seniman) dan pengembangan seni juga masyarakat, bukan seperti kewirausahaan yang pada umumnya bertujuan untuk menguntungkan diri sendiri;

3. BIPAF bekerja dengan berdasarkan kepada pemecahan masalah yang berada di dalam masyarakat (seni) untuk memberikan manfaat bersama, tidak seperti kewirausahaan konvensional yang membuat produk sesuai dengan tren di pasaran;

4. Akses modal BIPAF berasal dari dana caritas (CSR atau hibah, dan sebagainya), bukan berasal dari pemilik atau diupayakan sendiri;

5. Stakeholders BIPAF bukanlah pemasok, pelanggan, karyawan, atau investor, melainkan terdapat pula kelompok-kelompok lain yang menjadi sasaran program, perangkat pemerintah, dan unsur sebagainya, seperti seniman, produser, dan apresiator.

BIPAF telah mengantarkan para pelaku seni untuk mendapatkan panggung atau event yang lebih besar. Salah satu contohnya yakni para penampil BIPAF yang diundang ke Korean Festival tahun 2018, serta diundang mengikuti Student Exchange Program. Dengan demikian, BIPAF telah memberikan banyak ruang bagi para seniman yang mempertunjukkan karyanya untuk lebih memperkenalkan karyanya terhadap dunia yang lebih luas. Adanya BIPAF juga diharapkan dapat dendorong seniman dan masyarakat untuk kreatif dan inovatif dalam berwirausaha dan menyelesaikan masalah sosial. Selain itu, melalui proses yang panjang dalam mempersiapkan kesenian yang ditampilkan, masyarakat atau para apresiator yang hadir akan disuguhi pertunjukan yang berkualitas sehingga akan meningkatkan pengetahuan dan wawasannya tentang seni pertunjukan.

\section{DAFTAR RUJUKAN}

Bahren, Herry Nur Hidayat, Sudarmoko, Virtuous Setyaka. (2014). "Industri Kreatif Berbasis Potensi Seni dan Sosial Budaya di Sumatera Barat”. Jurnal Ekspresi Seni 16 (1): 133-155.

Dewiyanti, Ni Made, Made Antara, IB. Gde Pujaastawa. (2017) “Denpasar Festival' Mendukung Pariwisata Berbasis Ekonomi Kreatif Kota Denpasar". Jurnal JUMPA 3 (2): $238-251$.

Fittria, Anis. (2017). "Social Enterpreneurship dalam Perspektif Maqashid Al-Syariah". Jurnal Iqtisad 4 (1): 1-17.

Khairil, Muhammad dan Rizki Amelia Ranti. (2018) "Festival Pesona Palu Nomoni Dalam Pelestarian Budaya Kaili di Kota Palu". Jurnal KINESIK 5 (2): 79-87.

Koentjaraningrat. (2002). Pengantar Ilmu Antropologi. Jakarta: PT. Rineka Cipta.

Lab, Celsius Creative dan Wignoyo Parasian (Eds.) (2017) OPUS-BEKONOMI KREATIF Outlook 2017. Jakarta: BEKONOMI KREATIF.

Masunah, Juju, Trianti Nugraheni, Yudi Kusumayadi. (2018). "Building Performing Arts Community through Bandung Isola Performing Arts Festival (BIPAF) in Indonesia" in Advances in Social Science, Education and Humanities Research, Vol. 255, pp. 69-73. Atlantis Press.

Nurchayati dan Andalan Tri Ratnawati. (2016). "Strategi Pengembangan Industri Kreatif Sebagai Penggerak Destinasi Pariwisata di Kabupaten Semarang". Proceeding SENDI_U. Retrieved from https://www.unisbank.ac.id/ ojs/index.php/sendi_u/article/view/4271

Rahayu, Eva Martha. (2016). "Ketika Seni dan Kewirausahaan Menyatu dalam Ciputra Artpreneur". https://swa. co.id/swa/trends/management/ketika-seni-dan-kewirau- 
sahaan-menyatu-dalam-ciputra-artpreneur. Diakses tanggal 25/10/2019

Ridwan, Luthfi dan Astri Ghina. (2015). "A n a lis is Penerapan Social Bricolage di Social Enterprise”. E-Prosiding of Management 2 (1): 47-52. Bandung: Universitas Telkom.

Widiastuti, Ratna dan Meily Margaretha. (2011).

"Socio Enterpreneurship: Tinjauan Teori dan Peranannya Bagi Masyarakat”. Jurnal Manajemen 11 (1): 1-7. 